\title{
VASCULAR PLANTS AND PLANT HABITATS OF BRUSH CREEK ISLAND, LEWIS COUNTY, KENTUCKY, U.S.A.
}

\author{
Rudolphe A. Gelis ${ }^{1,2}$ \\ ${ }^{1}$ Yanayacu Biological Station and \\ Center for Creative Studies, Cosanga, Napo \\ c/o Foch 721 y Amazonas, Quito, ECUADOR \\ ${ }^{2}$ Biology Department, Berea College \\ Berea, Kentucky 40404, U.S.A. \\ rudygelis@yahoo.com
}

\author{
Ralph L. Thompson ${ }^{3,4,5}$ \\ ${ }^{3}$ Hancock Biological Station, 561 Emma Drive \\ Murray State University, Murray, Kentucky 40271, U.S.A. \\ ${ }^{4}$ Botanical Research Institute of Texas \\ 1700 University Drive, Fort Worth, Texas 76107, U.S.A. \\ ${ }^{5}$ Forestry Department, 2047 Big Hill Road \\ Berea College, Berea, Kentucky 40403, U.S.A. \\ ralph_thompson@berea.edu
}

\section{ABSTRACT}

\begin{abstract}
A descriptive survey of the vascular flora and plant habitats of Brush Creek Island, a 6.7-ha Ohio River island in Lewis County, Kentucky, was conducted during 1995-1996 and 2012. Brush Creek Island (BC), one of three Ohio River islands politically a part of Kentucky, is currently under private ownership and projected as a future part of the Ohio River Islands National Wildlife Refuge. Two major habitats in 2012 were Vegetated Unconsolidated Shoreline and Bottomland Hardwood Forest, a final sere of Late Old Field and Immature Bottomland Hardwood Forest. Two additional 1996 habitats, a seasonal Riverine Emergent Wetland and Late Old Field, were altered through fluvial action and secondary succession processes by 2012. An annotated list consists of 330 species in 220 genera from 82 families. Taxa are composed of one Monilophyte, four Magnoliids, 76 Monocots, and 249 Eudicots. Ninety-three taxa (28.2\%) are non-native adventive or naturalized species. Forty-eight taxa (54\%) are classified as Kentucky invasive plants. A total of 189 species (57.3\%) are hydrophytes. Ninety-five native or non-native taxa (28.8\%) are Lewis County distribution records.
\end{abstract}

KeY WorDs: Brush Creek Island, flora, habitats, invasives, Lewis County, Kentucky, Ohio River

\section{RESUMEN}

Se realizó un estudio descriptivo de la flora vascular y los hábitats de plantas de Brush Creek Island, una isla del río Ohio de 6,7 ha en el condado de Lewis, Kentucky, durante 1995-1996 y 2012. Brush Creek Island (BC), una de las tres islas del río Ohio, políticamente parte de Kentucky, actualmente es de propiedad privada y se proyecta como una parte futura del Refugio Nacional de Vida Silvestre de las Islas del Río Ohio. Dos hábitats principales en 2012 fueron la línea costera no consolidada con vegetación y el bosque de madera dura de tierras bajas, un último sere del campo viejo tardío y el bosque de madera dura de tierras bajas inmaduros. Dos hábitats adicionales de 1996, un humedal emergente fluvial estacional y un campo antiguo tardío, fueron alterados por acción fluvial y procesos de sucesión secundaria para 2012. Una lista anotada consta de 330 especies de 220 géneros y 82 familias. Los taxones se componen de un monilophyta, cuatro magnoliidas, 76 monocotiledóneas. y 249 eudicotiledóneas. Noventa y tres taxones $(28,2 \%)$ son especies adventiceas o naturalizadas no autóctonas. Cuarenta y ocho taxones (54\%) están clasificados como plantas invasoras de Kentucky. Un total de 189 especies (57,3\%) son hidrófitas. Noventa y cinco taxones nativos o no nativos $(28,8 \%)$ son registros de distribución del condado de Lewis.

PALABRAS CLAVE: Isla Brush Creek, flora, hábitats, invasores, condado de Lewis, Kentucky, río Ohio

\section{INTRODUCTION}

Brush Creek Island (BC), a 6.7-ha spindle-shaped, perched island, is one of three Ohio River islands politically a part of Lewis County, Kentucky (Fig. 1). Brush Creek Island is currently under the private ownership of the Earl Parr estate, Ashland, Kentucky. BC has been projected to become a future part of the Ohio River National Wildlife Refuge (Tolin \& Schettig 1983).

The other two Lewis County islands, Manchester No. 1 (10.9-ha), and Manchester No. 2 (46.5-ha), are part of the Ohio River National Wildlife Refuge (ORINWR) located 13.3-13.6 km downstream from BC (Tolin \& Schettig 1983). The ORINWR was established in 1990 to protect 22 islands and their backwater channels for their high quality of fish and wildlife, recreation, natural heritage, geological uniqueness, and scientific value along a 203-km corridor of the Ohio River from Pennsylvania, West Virginia, and Kentucky (ORINWR 2002).

We began a comprehensive study of Brush Creek Island flora and vegetation throughout the growing seasons of 1995-1996. The survey was reinitiated and concluded in 2012 with comparisons made between the 


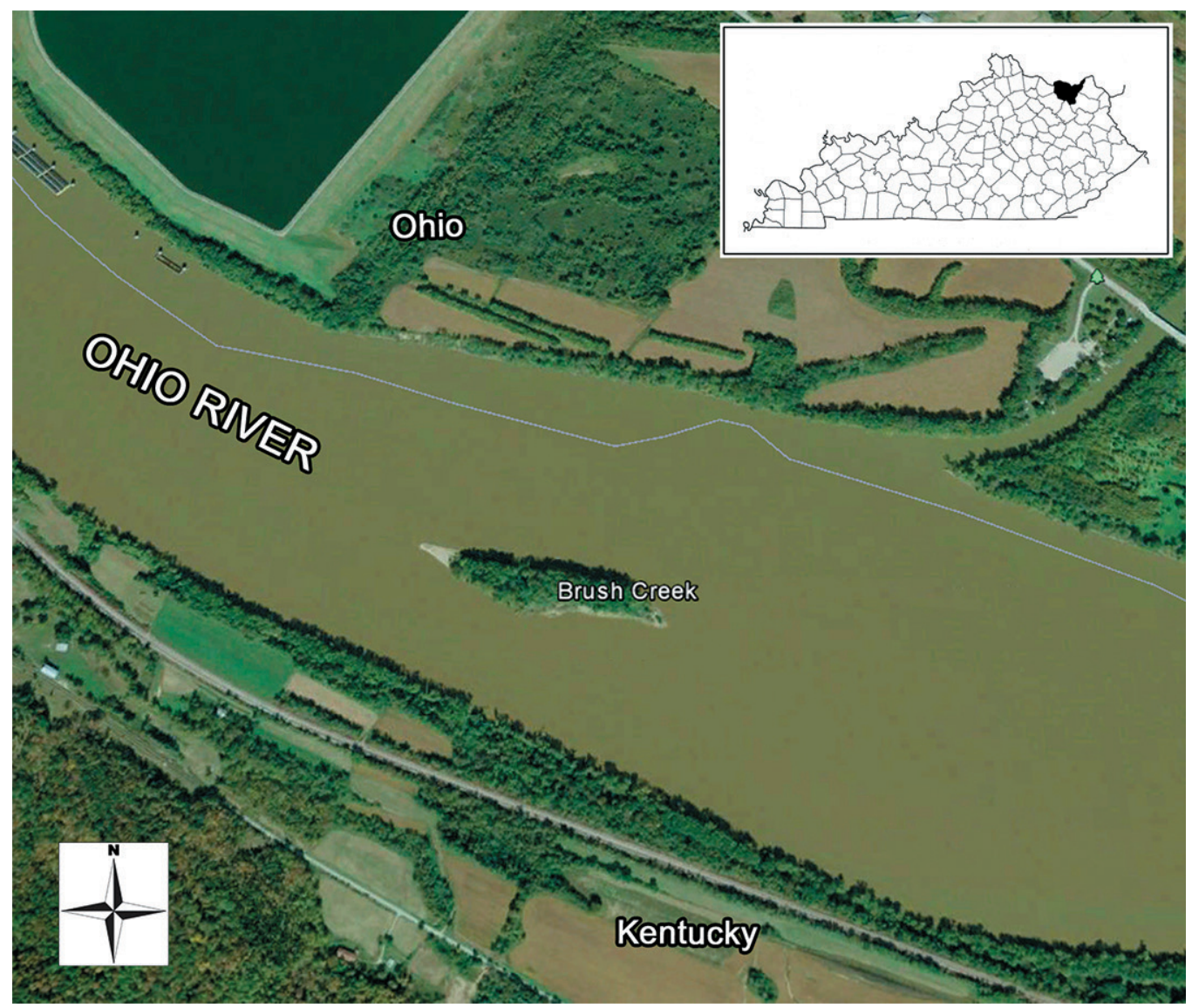

FiG. 1. Brush Creek, a 6.7-ha Ohio River Island, Lewis County, Kentucky, adapted from the Concord and Buena Vista Quadrangle by Melanie Givan from Google Earth Pro 2016 image.

flora and habitats from fluvial processes of the Ohio River and natural secondary succession after 16 years. The descriptive study represents the first complete floristic survey of Brush Creek Island since a reconnaissance by Tolin and Schettig (1983). Gelis (1996) conducted and published a bird survey of Brush Creek, Manchester No. 1, and Manchester No. 2 concurrently with this flora project.

Our study objectives were to: 1) conduct a thorough floristic survey to document all vascular plants with representative herbarium voucher specimens; 2) prepare an annotated species list with Lewis County distribution records, non-native plant origin, invasive plant status, vernacular name, habitats, relative abundance, and federal wetland status; 3 ) describe plant habitats and associated taxa within the BC terrestrial boundary; and, 4) produce detailed flora and vegetation baseline data of Brush Creek Island for refuge personnel, educators, and scientists.

The flora and vegetation of freshwater river islands in the eastern United States have been published in Wisconsin (Barnes 1978, 1991), Pennsylvania (Whitbeck et al. 1997; Walters \& Williams 1999; Williams 2010a), and Kentucky (Vance et al. 2014). Riverine ecosystems are among the most dynamic and rich of ecological systems, and riverine corridors are major determinants of plant distribution patterns due to fluvial and hydrologic processes (Naiman \& DéCamps 1997; Naiman et al. 2005).

River flooding regimes greatly influence plant species richness. Spatial dispersal patterns (zones) change 
as distance increases from riverwash (sand, silt, clay mudflats) and island riverbanks to first and second bottoms of flood plain bottomland hardwood forests (Barnes 1978). These spatial dispersion factors are correlated to alluvial soils, flood frequency and duration, drainage, topography, light conditions, and elevation of the islands (Barnes 1978).

Vascular plant species richness of riparian areas often exceeds species richness of adjacent upland areas (Naiman \& DéCamps 1997; Hood \& Naiman 2000; Naiman et al. 2005). The greatest species richness (number of species) was forbs rather than graminoids or woody taxa in two Pennsylvanian river island studies (Walters \& Williams 1999; Williams 2010b) and in Kentucky (Vance et al. 2014).

Plant assemblages continuously change due to fluvial processes throughout the growing seasons. The migration, establishment, colonization, and spread of naturalized non-native taxa, particularly invasives, have resulted in the reduction and in some cases, the elimination of native species, as well as altered ecosystem structure and function, propagule dispersal, regeneration, and nutrient cycling (Walters \& Williams 1999; Richardson et al. 2000, 2007; Williams 2010a).

The dominant vegetation of Brush Creek Island is Bottomland Hardwood Forest (BHF), a climax sere derived from sub-sere Late Old Field and Immature Bottomland Forest (Tolin \& Schettig 1983; ORINWR 2002). As an isolated riverine island, BC has been relatively free from human destruction and manipulation, such as what has occurred in the nearby Bluegrass Section of the Western Mesophytic Forest Region (Braun 1950; Tolin \& Schettig 1983). Woods et al. (2002) placed northwestern forested Lewis County in the northern glaciated Outer Bluegrass Ecoregion of the Interior Low Plateaus Province. The remaining forested terrain of Lewis County is characterized by various stands of Mixed Oak-Hickory Forest (Woods et al. 2002), or classified as Mesophytic Forest (Dyer 2006).

\section{THE STUDY AREA}

Brush Creek Island is located in the Meldahl Navigation Pool of the Ohio River below Greenup Dam between $\mathrm{km} 624.25$ and $\mathrm{km}$ 625.05, and $0.63 \mathrm{~km}$ north from Chalkey Station and $3.1 \mathrm{~km}$ ESE of Concord, Lewis County, Kentucky. The island center lies at latitude (38 $\left.40^{\prime} 17.8^{\prime}\right)$ and longitude (83 $\left.27^{\prime} 35.7^{\prime \prime}\right)$, within the Concord and Buena Vista Quadrangle (Fig. 1). The 6.7-ha island has a circumnavigated shoreline perimeter of $1.2 \mathrm{~km}(0.40 \mathrm{~km}$ long $\times 0.10 \mathrm{~km}$ wide) (Tolin \& Schettig 1983). Elevations fluctuate from $146 \mathrm{~m}$ at island river surface to $158 \mathrm{~m}$ on the uppermost perched island terrace (Morris 1966).

Moderate to heavy erosion occurs when the flow energy of the Ohio River exceeds the resistance of shoreline and island materials. Springer et al. (1984) described erosion of alluvial streambanks and island soils along the Ohio River through the "sliding wedge mechanism," an erosion process involving sand and silt partings on upper bank layers that underlie cohesive upper soil layers being lost when alluvial soils slump or collapse from the fluvial action floodwater regimes.

Ohio River fluvial processes included the erosion, transportation, and deposition of alluvial sediments and other materials to and from the island head, channel side, backwater side, and toe of Brush Creek Island (Figs. 1, 2). Brush Creek Island is characterized by moderate to severe erosion during winter and spring floods at the shallow water zone off the tapered head with exposed and submerged logs becoming embedded in sand, gravel, and cobbles (Fig. 2). At high velocity current, the Ohio River erodes sand, silt, mud, and lighter detritus most strongly from the uppermost tapered island head to moderate erosion on the swift channel side to low erosion on the slower steep backwater channel. Light sand, silt, and clay sediments, muck, and detritus accumulate on the slender island toe (Tolin \& Schettig 1983).

Ohio River islands were formed by the accretion of alluvium from the Recent Series of the Quaternary System and have been greatly influenced by geologic processes during the Pleistocene and Holocene Epochs (Morris 1966). BC was formed by the accumulation of fluvial deposits over gravel and rock bars to the height of the annually flooded Ohio River floodplain (Tolin \& Schettig 1983).

At BC, Wheeling and Nolin alluvial soils belong to the fine sandy and/or silt loams of the WheelingNolin-Otwell Complex (Jacobs \& Jones 2004). Wheeling loam soils are medium acid, moderately 


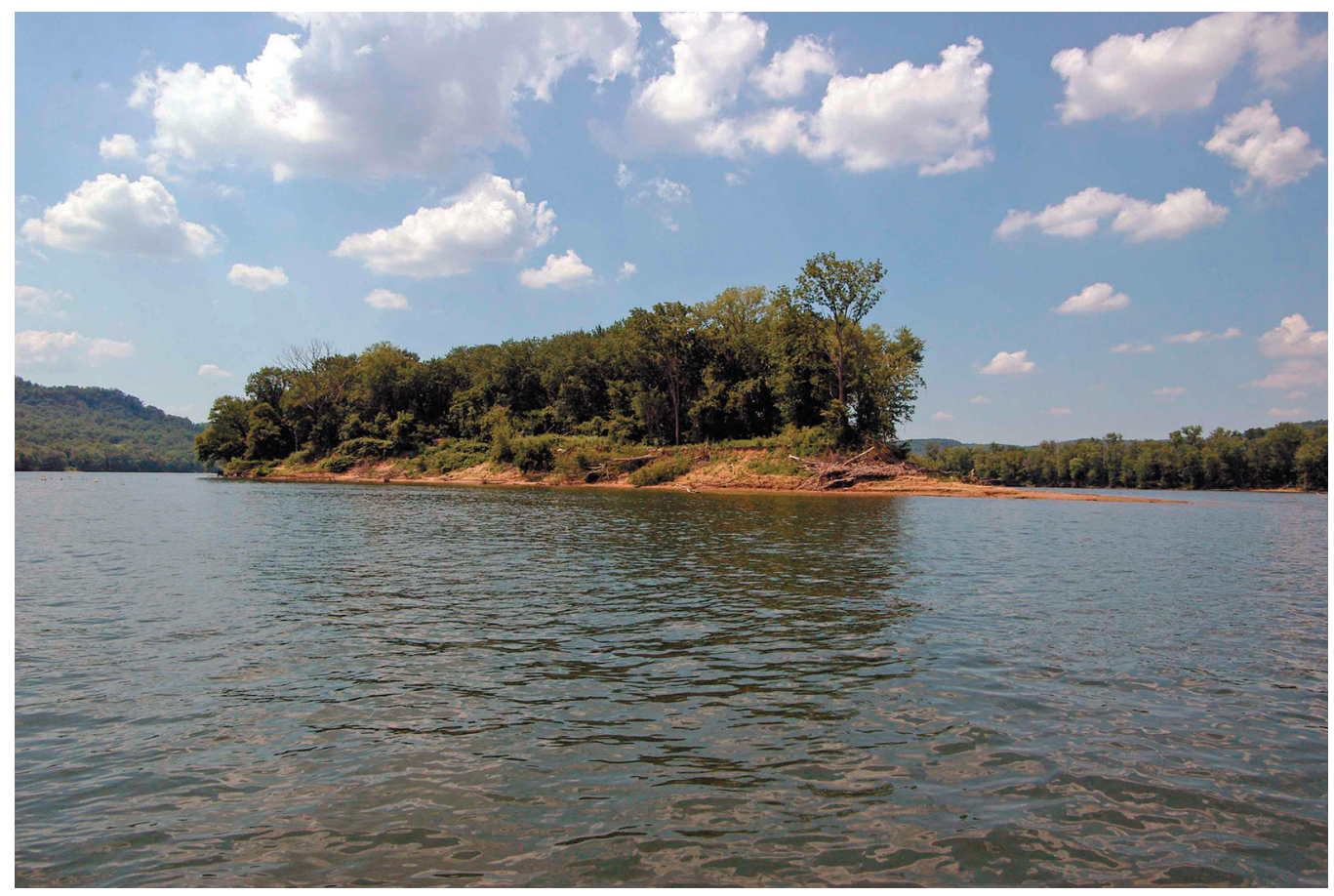

FIG. 2. Brush Creek Island, Kentucky, south view on steep, backside channel with exposed and submerged logs at the tapered head. (Photo courtesy of Tom Cross, Executive Director, Adams County Travel and Visitor Bureau, West Union, Ohio).

well-drained, mixed alluvium of sand, silt, clay, and some gravel over $152 \mathrm{~cm}$ in depth with minor soil profile development. Wheeling soils are found on infrequently flooded upper terraces near the perched island center at approximately 156-158 m elevation (Jacobs \& Jones 2004). Nolin silt loam soils are medium acid to alkaline, well-drained, mixed loamy sand, silt, and clay alluvium less than $152 \mathrm{~cm}$ deep with little soil profile development. Nolin soils are present on annually flooded lower terraces at approximately 144-148 m where considerable seasonal alluvium deposition occurs (Jacobs \& Jones 2004). Mean two-year floods typically reach elevations of 154-158 m on the high terraces (Jacobs \& Jones 2004).

Kentucky climate is continental temperate, humid mesothermal characterized by hot summers and mild to cold winter temperatures (Trewartha \& Horn 1980). Midwest climatic summary data (1981-2010) were derived from the Maysville Sewage Plant station (155243) weather station bordering the Ohio River in the surrounding areas west of Brush Creek (MRCC 2019). The median growing season was 186 days at $0^{\circ} \mathrm{C}$ with the median first frost in late October and the median last frost in middle April. The mean annual temperature was $12.5^{\circ} \mathrm{C}$ with the coldest months January-February $\left(\sim 0.6^{\circ} \mathrm{C}\right)$ and the warmest months July-August $\left(\sim 24^{\circ} \mathrm{C}\right)$. Mean annual rainfall precipitation was $103 \mathrm{~cm}$ and $56 \mathrm{~cm}$ of snowfall (MRCC 2019).

\section{MATERIALS AND METHODS}

Boat transportation to Brush Creek Island for reconnaissance and specimen collections was provided by our personal boat or ORINWR personnel craft. Standard collection and specimen procedures were employed. Manuals for identification were: Beal and Thieret (1986); Jones (2005); and Weakley (2015). Plant clades, families, and nomenclature follow Weakley (2020).

A master set of representative voucher specimens are deposited in the Berea College, Ralph L. Thompson Herbarium (BEREA), now part of the Ronald L. Jones Herbarium of Eastern Kentucky University (EKY). 
Partial duplicate sets are on file in EKY and the Northern Kentucky University, John W. Thieret Herbarium (KNK). BC specimens are publicly accessible through the SERNEC Data Portal (2021).

An annotated species list is arranged alphabetically by families, genera, species and infraspecific taxa within major vascular plant groups. Symbol codes for each taxon entry in the annotated list before the scientific name are: (o) Lewis County distribution records (Campbell \& Medley 2006, 2012, 2020); (*) non-native plant origin (Weakley 2020; USDA, NRCS 2021); and (**) Kentucky invasive species status (KY-EPPC 2013).

Following every scientific name, a common name (Weakley 2020; USDA, NRCS 2021), an inclusive relative abundance value (Thompson \& Rivers Thompson 2016), plant habitats (Tolin \& Schettig 1983), a National Wetland Plant List (NWPL) rating for Kentucky (Lichvar 2013), and a representative BC plant voucher number or numbers, are provided.

Wetland plant habitats adapted from Tolin and Schettig (1983) are: Vegetated Unconsolidated Shoreline (US), Riverine Emergent Wetland (REW), Late Old Field (LO), and both Immature Bottomland Forest (IB) and Mature Bottomland Forest (MB). In our study, IB and MB mosaics are treated as Bottomland Hardwood Forest (BHF).

Major Brush Creek Island habitats were delineated through field reconnaissance, field collections, physical site characteristics (general topographic-moisture regimes, slope aspect, flood elevation, fluvial frequency, light conditions, species composition), associated species, and belt transect sampling. Associated plant species (associates) are characteristic or indicator native and non-native taxa which possess a similar phenological life cycle, plant duration, ecological adaptation, and habitat requirements (Thompson \& Rivers Thompson 2016).

A relative abundance scale inclusive for each taxon from all plant habitats is derived from Thompson and Rivers Thompson (2016): R (Rare); S (Scarce); I (Infrequent); O (Occasional); F (Frequent); and A (Abundant).

National wetland indicator status classification in the Eastern Mountains and Piedmont including Kentucky (Lichvar 2013) are: OBL (Obligate Wetland); FACW (Facultative Wetland); FAC (Facultative); FACU (Facultative Upland); UPL (Upland); and NI (Non-indicator).

During October 2012, thirty $(2 \mathrm{~m} \times 100 \mathrm{~m})$ belt transects were situated within the Bottomland Hardwood Forest for a tree population analysis by size-classes $(\mathrm{dm})$ for species composition based on Daubenmire (1968). Fifteen belt transects were situated on each of the two well-defined BHF terraces: the first bottom terrace, annually flooded adjacent to the US at the Ohio River, and the second bottom terrace, rarely-flooded adjoining the first bottom terrace. Size-class species categories [diameter breast height (DBH) measured at $1.37 \mathrm{~m}$ above ground] adapted from Vance et al. (2014) were: tree seedlings ( $<1.0 \mathrm{~m}$ tall, $2.5 \mathrm{~cm} \mathrm{DBH})$; saplings (> $1.0 \mathrm{~m}$ tall, $2.5-4.9 \mathrm{~cm} \mathrm{DBH})$; small trees or poles (4.9-9.9 cm DBH); trees (1-16 dm DBH).

RESULTS AND DISCUSSION

\section{The Taxonomic Summary}

Vascular flora of Brush Creek Island consists of 330 specific and infraspecific taxa in 220 genera from 82 families (Table 1). Vascular plants include: one Monilophyte, four Magnoliids, 76 Monocotyledonae, and 249 Eudicotyledonae (Table 1). A total of 330 taxa are composed of 289 herbaceous plants and 50 woody plants: 23 trees (20 native, 3 non-native); 15 shrubs (12 native, 3 non-native); and 12 vines (10 native, 2 non-native).

The five largest families in number of species are: Asteraceae (46), Poaceae (41), Cyperaceae (19), and 12 each from Lamiaceae and Polygonaceae. The ten largest families in terms of taxa account for 173 (52.4\%) of 330 taxa (Table 2). Carex (7), Persicaria (6), and Symphyotrichum (5) are the largest genera. Ninety-five (26 Monocots, 69 Dicots) native or non-native taxa (28.8\%) are Lewis County distribution records.

Vance et al. (2014) conducted an ecological study of three ORINWR islands (Blennerhassett, Buckley, and Muskingum) in West Virginia. From 31 quadrats sampled, they recorded 170 species that consisted of 39 woody species (29 trees, 10 shrubs and woody vines) and 131 herbs. In comparison, Brush Creek Island had $160(94.0 \%)$ of the 170 taxa recorded by Vance et al. (2014); BC only lacked 11 species ( 4 trees, 1 woody vine and 6 herbs) within its 330 species. 
TABLE 1. Taxonomic distribution of vascular plants of Brush Creek Island, Lewis County, KY.

\begin{tabular}{llllllll}
\hline Clade & Family & Genera & Species & Native & Exotic & Invasive & Species \% \\
\hline Monilophyta & 1 & 1 & 1 & 1 & 0 & 0 & 0.30 \\
Magnoiids & 3 & 4 & 4 & 4 & 0 & 0 & 1.21 \\
Monocotyledonae & 12 & 43 & 76 & 56 & 20 & 13 & 23.03 \\
Eudicotyledonae & 66 & 172 & 249 & 176 & 73 & 35 & $\mathbf{4 3}$ \\
\hline Total: & $\mathbf{8 2}$ & $\mathbf{2 2 0}$ & $\mathbf{3 3 0}$ & $\mathbf{2 3 7}$ & $\mathbf{9 3}$ & $\mathbf{4 8}$ & $\mathbf{1 0 0 . 0 0}$ \\
\hline
\end{tabular}

TABLE 2. Species richness of 10 largest families of Brush Creek Island, Lewis County, KY.

\begin{tabular}{lllllll}
\hline Family & Genera & Species & Native & Exotic & Invasive & Species \% \\
\hline Asteraceae & 30 & 46 & 38 & 8 & 4 & 13.94 \\
Poaceae & 27 & 41 & 26 & 15 & 9 & 12.42 \\
Cyperaceae & 5 & 19 & 18 & 1 & 0 & 5.76 \\
Polygonaceae & 5 & 12 & 5 & 7 & 3 & 3.64 \\
Lamiaceae & 11 & 12 & 9 & 3 & 3 & 3.64 \\
Brassicaceae & 8 & 11 & 3 & 8 & 3 & 2.33 \\
Fabaceae & 9 & 9 & 6 & 3 & 2 & 2.42 \\
Rosaceae & 6 & 8 & 6 & 2 & 0 & 2.42 \\
Solanaceae & 3 & 8 & 5 & 3 & 1 & $\mathbf{2 . 1 2}$ \\
Ranunculaceae & 4 & 7 & 4 & 3 & $\mathbf{2 8}$ & $\mathbf{5 2 . 4 2}$ \\
\hline Total: & $\mathbf{1 0 8}$ & $\mathbf{1 7 3}$ & $\mathbf{1 2 0}$ & $\mathbf{5 3}$ & & \\
\hline
\end{tabular}

The ORINWR (2002) Final Comprehensive Conservation Plan with an updated refuge 2016 plant list contained 552 species ( 66 trees, 53 shrubs and woody vines, and 433 herbs). The Brush Creek Island list documented 296 species, or (53.6\%), of all reported ORINWR plants, including 23 trees, 24 shrubs and woody vines, and 249 herbs

\section{Rare and Significant Native Species}

Four Kentucky rare species (OKNP 2019) documented at Brush Creek Island were Heracleum maximum (Historic), Ripariosida hermaphrodita (Threatened), Senecio suaveolens (Special Concern), and Vallisneria americana (Special Concern). On Brush Creek Island, three of four state-listed taxa were collected in an existing LO habitat, and V. americana from aquatic beds along the Unconsolidated Shoreline during 1995 (Abbott et al. 2004). Campbell and Medley (2020) mapped only Lewis, Greenup, and Harlan counties for Heracleum maximum, and seven Kentucky counties bordering the Ohio River for Ripariosida hermaphrodita. Senecio suaveolens was collected in the BHF as a Lewis County distribution record (Abbott et al. 2004); it had been mapped by Campbell and Medley(2020) in 10 Kentucky counties. Senecio suaveolens, a predominately perennial riparian flood plain species, has been listed as a "special concern" in 13 eastern U.S. states (Williams 2010b). Vallisneria americana has been vouchered in eight Kentucky counties according to Campbell and Medley (2020). Floerkea proserpinacoides and Valliseria americana were also Lewis County range extension plants from BC (Abbott et al. 2004). The rare Bromus latiglumus, documented in the LO and BHF, have been reported only in Lewis and Pulaski counties by Campbell and Medley (2020).

\section{Naturalized and Invasive Exotics}

A total of 93 non-native (alien, exotic, non-indigenous) taxa were documented at BC. Forty-eight (51.6\%) of the 93 naturalized taxa (20 monocots, 73 dicots) were Kentucky state-listed invasives (Table 1). Invasives were: 23 Severe-Threat, 13 Significant-Threat, eight Moderate-Threat, and four Watch List plants (KY-EPPC 2013). The Severe-Threat invasive species with the greatest impact on BC native flora and vegetation included: Achyranthes japonica, Alliaria petiolata, Arthraxon hispidus, Celastrus orbiculatus, Glechoma hederacea, Lonicera japonica, L. maackii, Microstegium vimineum, Reynoutria japonica, Rosa multiflora, Sorghum halepense, and 
Stellaria media. Severe-threat and many significant-threat invasives may be termed "transformers," a subset of invasives that clearly alter the character and nature of ecosystems over substantial areas through time (Richardson et al. 2000, 2007).

Abbott et al. (2004) documented Achyranthes japonica, Cardamine impatiens, Filicaria verna, and Stellaria aquatica as Kentucky range extensions on BC. Non-native classification includes 87 naturalized taxa and six adventive annuals (likely just waifs): Cannabis sativa, Citrullus lanatus, Cucurbita pepo, Solanum lycopersicum, S. sarrachoides, and Tarenaya hassleriana. Schwartz et al. (2016) reported Achyranthes japonica, an invasive Asian perennial, in essentially all counties of states bordering the Ohio River and upper tributaries down to its confluence with the Mississippi River.

\section{National Wetland Taxa}

A total of 189 wetland species (57.3\%) classified as hydrophytes on the National Wetland Plant List (NWPL) were present at Brush Creek Island: OBL (38 taxa), FACW (76 taxa), and FAC (75 taxa). This significant number of wetland plants may be attributed mainly to the fluvial action of the Ohio River on the Vegetated Unconsolidated Shoreline and the Riverine Emergent Wetland habitats. The Late Old Field and Bottomland Hardwood Forest habitats contained the majority of non-hydrophyte species: FACU (99 taxa) and UPL (18 taxa). These non-hydrophytes demonstrated plant adaptability to the less infrequently-flooded terrestrial habitats. Twenty-four NI (non-indicator) taxa were also documented.

\section{Plant Habitats}

Tolin and Schettig (1983) are followed for terrestrial and wetland habitats during this study. Plant habitats, associates, and secondary succession on BC are described through three time periods: 1983, 1995-1996, and 2012. BC habitats have been considerably altered or modified through secondary succession processes and annual seasonal fluvial effects of the Ohio River over the 29-year time period of this survey: 1983 to 19951996 (13 years) and from 1996 to the final 2012 survey (16 years). These habitats are described for each survey with their associated plants.

\section{Plant Survey and Habitats}

Tolin and Schettig (1983) conducted a reconnaissance survey of Brush Creek Island (6.76 ha) from four mapped habitats: Vegetated Unconsolidated Shoreline (US), 0.81 ha; Late Old Field (LO), 2.55 ha; Immature Bottomland Hardwoods (IB), 0.12 ha; and Mature Bottomland Hardwoods (MB), 3.28 ha. They listed a total of 54 plant taxa: 14 trees, 5 shrubs and woody vines, and 35 herbs. In their IB and MB habitats, the dominant canopy trees were: Acer negundo, Acer saccharinum, Juglans nigra, Platanus occidentalis, Populus deltoides, Robinia pseudoacacia, and Salix nigra (Tolin \& Schettig 1983).

\section{5-1996 Plant Survey: Habitats and Associated Plants}

The LO and IM habitats at BC designated by Tolin and Schettig (1983) had progressed through secondary succession stages over those 13 years into four major habitats during the 1995-1996 survey: Vegetated Unconsolidated Shoreline (US) 0.80 ha; Riverine Emergent Wetland (REW) 0.01 ha; Late Old Field (LO) 1.8 ha; our Bottomland Hardwood Forest (BHF), 4.1 ha; and a consolidated mixture including some earlier LO and Immature Bottomland Forest (IB).

Vegetated Unconsolidated Shoreline (US).- This riverine habitat is maintained by annual seasonal winter and spring flooding of the Ohio River that scours and erodes the island head, channel side, backwater channel, and toe. The 2.0-ha US habitat mapped by Tolin and Schettig (1983) remained about the same sizedarea in 1995-1996. The Ohio River substrate is mainly composed of mud, silt, and sand intermixed with small gravel in a near level gradient. River fluctuations regularly disturb and eliminate plants while also dispersing seed propagules to reestablish those plants and new plants on these "new seasonally dewatered sand and mudflats."

In the spring, the unstable US is mostly bare of plants from scouring winter and spring flood action, while dense low herbaceous vegetation covers the seasonal dewatered sand and mudflats during the summer 
and early fall as the Ohio River levels recede. The US habitat has a moderately high species richness with flora dominated by pioneering, seasonal native and non-native annuals, biennials, perennials (functioning as annuals), and true perennial herbs.

Woody plants less than $10 \mathrm{~m}$ tall occupied the US habitat on the island head and channel side to the toe. Abrasive mechanical damage occurred from seasonal heavy flooding, and first year saplings often did not persist. Characteristic shrub-scrub woody plants with extensive underground roots colonize the US habitat adjacent to the BHF first terrace (first bottoms) included seedlings and saplings of Acer saccharinum, Amorpha fruticosa, Betula nigra, Cephalanthus occidentalis, Cornus amomum, Platanus occidentalis, Populus deltoides, Salix interior, and S. nigra.

Equisetum arvense was an indicator spring species of the vegetated US zone. Characteristic summer-fall mudflat graminoids were Cyperus bipartitus, C. erythrorhizos, C. esculentus, C. odoratus, C. squarrosus, C. strigosus, Echinochloa muricata, Eragrostis hypnoides, E. pectinacea, Fimbristylis autumnalis, Panicum dichotomiflorum, and Paspalum fluitans.

Native and non-native sand and mudflat summer-fall forbs [Amaranthus-Bidens-Cyperus-Persicaria Community] included Abutilon theophrasti, Acalypha rhomboidea, Ammannia coccinea, Amaranthus spinosus, A. tuberculatus, Artemisia annua, Bidens cernua, B. frondosa, Datura stramonium, Diodia virginiana, Dysphania ambrosoides, Eclipta prostrata, Euphorbia humistrata, E. maculata, Leucospora multifida, Lysimachia nummularia, Mollugo verticillata, Oxalis stricta, Persicaria spp., and Xanthium chinense, among numerous other taxa. Rare or scarce adventives were Cannabis sativa, Citrullus vulgaris, Cucurbita pepo, and Solanum lycopersicum. Williams (2010a) found the flood plain scour community (i.e., our US habitat) had the greatest non-native species richness in a survey of seven islands in the Allegheny River Islands Wilderness, Pennsylvania.

Riverine Emergent Wetland (REW)._-In 1995 and 1996, a small seasonal Riverine Emergent Wetland [Carex-Cyperus-Eleocharis Community] was present on the channel side near the island head between the US and the BHF lower terrace border. The REW was formed when severe erosion scoured a shallow depression (ca. $40.0 \mathrm{~m}$ long $\times 8.0 \mathrm{~m}$ wide) prior to 1995 . Several FACW and OBL wetland annuals and perennial graminoids and forbs occupied the REW.

Indicator wetland emergents were Alisma subcordatum, Ammannia coccinea, Asclepias incarnata, Carex tribuloides, C. vulpinoidea, Cicuta maculata, Cyperus esculentus, C. erythrorhizos, C. strigosus, C. odoratus, Eleocharis erythropoda, E. obtusa, Glyceria striata, Hypericum mutilum, Juncus acuminatus, J. interior, Justicia americana, Leersia oryzoides, Lindernia dubia, Ludwigia alternifolia, L. decurrens, L. palustris, Lycopus americanus, L. virginicus, Lythrum salicaria, Mimulus alatus, Rorippa palustris var. fernaldiana, Sagittaria calycina, Samolus parviflorus, Schoenoplectus tabernaemontani, Scutellaria lateriflora, and Spermacoce glabra. This REW habitat was not present on BC during the survey of Tolin and Schettig (1983) and the REM habitat was extirpated before 2012 .

Late Old Field (LO).- This successional habitat [Rosa-Rubus-Sambucus-Vitis Community] was characterized by perennial herbs and woody vines on the upper terrace near the island head and is enclosed by the BHF. Because of significant insolation, the LO included many species of the late old field habitat of Tolin and Schettig (1983). The LO was seasonally flooded with less regularity and intensity, ca. every 5-10 years, than the lower bottom or first shoreline terrace adjacent to the US; the LO consisted of a high number of species.

Shrubs, woody vines, and trees included a conglomeration of Acer negundo, Ampelopsis cordata, Celastrus orbiculatus, Rosa multiflora, Rubus occidentalis, R. pensilvanicus, Sambucus canadensis, Toxicodendron radicans, Vitis riparia, and V. vulpina. Typical non-native spring herbaceous taxa were Achyaranthes japonica, Alliaria petiolata, Cardamine hirsuta, Cardamine impatiens, Daucus carota, Glechoma hederacea, Hesperis matronalis, Humulus japonicus, Lamium purpureum, and Stellaria media. Representative native spring and summer to fall herbs included Carex blanda, C. grisea, Chaerophyllum procumbens, Convoluvus sepium, Erigeron annuus, E. philadelphicus, Euthamia graminifolia, Eutrochium fistulosum, Fallopia scandens, Galium aparine, Phalaris arundinacea, Phytolacca americana, Potentilla norvegica, Ranunculus abortivus, Rudbeckia laciniata, Sicyos angulatus, Solidago altissima, Urtica gracilis, Verbesina alternifolia, and Vernonia gigantea among others. 
Bottomland Hardwood Forest (BHF)._-Tolin and Schettig (1983) classified the Mature Bottomland (i.e., our BHF) as the climax (final sere) of the flood plain plant community. By 1995-1996, the LO and IB habitats represented a mosaic toward the dominant Bottomland Hardwood Forest (BHF) based upon forest stand structure and number of canopy tree species.

A mature BHF flood plain stand included Acer negundo, A. saccharinum, Celtis occidentalis, Juglans nigra, Populus deltoides, Platanus occidentalis, and Ulmus americana [Acer-Celtis-Juglans-Platanus-Populus-Ulmus Community]. The four-layered vegetation; herb, shrub, subcanopy, and canopy layers, comprised the greatest species richness of the $\mathrm{BC}$ habitats. Indicator woody shrubs and vines included Ampelopsis cordata, Asimina triloba, Campsis radicans, Lindera benzoin, Lonicera japonica, L. maackii, Menispermum canadense, Parthenocissus quinquefolia, Sambucus canadensis, Toxicodendron radicans, Vitis riparia, and V. vulpina.

Characteristic native spring herbs were Carex davisii, C. grayi, Chaerophyllum procumbens, Claytonia virginica, Corydalis flavula, Floerkea proserpinacoides, Galium aparine, Polygonatum biflorum, Ranunculus abortivus, Viola sororia, and V. striata. Typical summer and fall native herbs were Ageratina altissima, Bromus latiglumus, Chasmanthium latifolium, Cinna arundinacea, Conoclinium coelestinum, Cryptotaenia canadensis, Eurybia divaricata, Geum canadense, Helianthus tuberosus, Impatiens capensis, I. pallida, Laportea canadensis, Leersia virginica, Muhlenbergia frondosa, Persicaria virginiana, Pilea pumila, Rudbeckia laciniata, Solidago gigantea, Symphyotrichum ontarionis, Thalictrum pubescens, Urtica gracilis, and Verbesina alternifolia. The majority of invasive herbs, Achyranthes japonica, Alliaria petiolata, Cardamine hirsuta, Glechoma hederacea, Lamium purpureum, Microstegium vimineum, Reynoutria cuspidata, and Stellaria media, were present in the BHF.

\section{Plant Survey: Habitats and Associated Species}

Secondary plant succession and fluvial processes from 1995-1996 to 2012 changed the physical features, habitats, and flora over that 16-year period on Brush Creek Island.

Vegetated Unconsolidated Shoreline (US). - The US had not significantly changed in surface area ( 0.81 ha) nor in species richness since 1996 (Fig. 3). Curcurbita pepo, Cyperus flavescens, Dysphania botrys, Euphorbia humistrata, Ipomoea purpurea, and Mazus pumilus were a few new taxa collected, while several US species had vanished.

Riverine Emergent Wetland (REW).- The REW habitat was non-persistent and had disappeared by 2012 and the temporary area had been incorporated within the vegetated US sand and mudflat zone. Several unique OBL and FACW taxa were extirpated from BC presumably through fluvial processes between 1996 and 2012. REM wetland missing emergents included Alisma subcordatum, Carex vulpinoidea, Cicuta maculata, Eleocharis erythropoda, Juncus interior, Justicia americana, Sagittaria calycina, Samolus parviflorus, Schoenoplectus tabernaemontani, and Spermacoce glabra among others.

Late Old Field (LO).-The LO habitat was partly assimilated into an expanded BHF habitat through progressive secondary succession, and many of the annual and perennial graminoids and forbs adapted or were lost as the LO sub-sere changed with the variation in insolation to the BHF habitat and the establishment and colonization by more shade-tolerant herbaceous and woody species.

Bottomland Hardwood Forest (BHF).- - The largest and most stable habitat ( $\sim 5.7$ ha) has continued to expand by consolidation of the LO and the IM habitats (Fig. 3). The lower flood plain terrace continues to be inundated during annual high fluvial action of the Ohio River and the perched upper terrace only infrequently inundated for brief periods during high Ohio River flood levels. Woody and herbaceous taxa were largely those colonizers from 1995-1996 BHF and the advent of the LO and IM taxa adapting to less insolation and more shade-tolerant conditions.

A size-class distribution analysis of 18 understory and overstory trees sampled in October 2012 is presented in Table 3. The largest canopy trees in DBH were: Populus deltoides (121, 160, $187 \mathrm{~cm})$; Platanus occidentalis (90, 107, $166 \mathrm{~cm}$ ); Acer saccharinum (95, 104, $107 \mathrm{~cm}$ ); Robinia pseudoacacia (50, 61, $63 \mathrm{~cm}$ ); Juglans nigra $(56,59,61 \mathrm{~cm})$; Acer negundo $(38,40,51 \mathrm{~cm})$; and Ulmus americana $(43,53,57 \mathrm{~cm})$.

Permanent tree occupants based on seedlings, saplings, small trees (poles), and canopy trees in continuing decimeter size-classes were: Acer saccharinum, A. negundo, Ulmus americana, and Celtis occidentalis (Table 


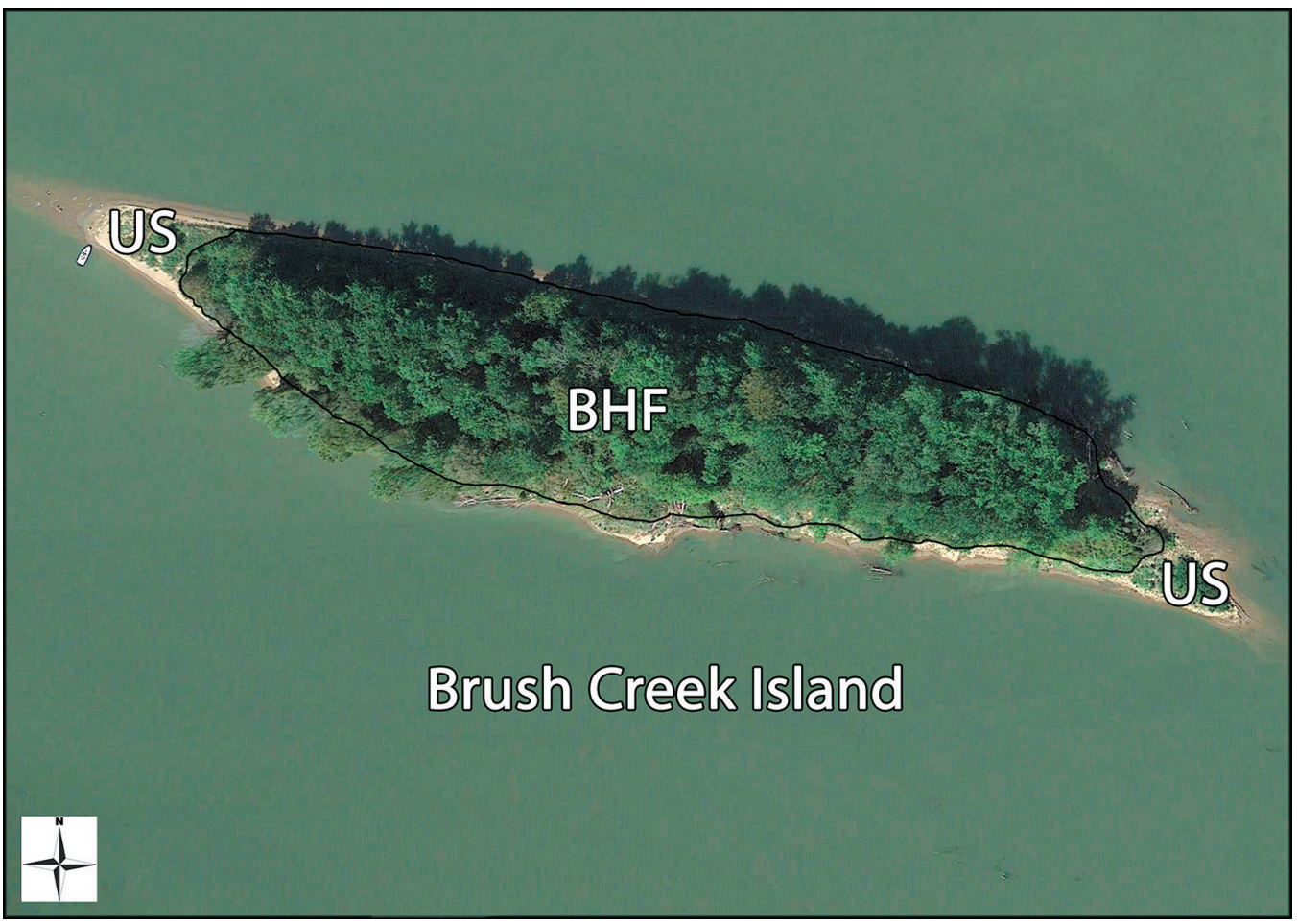

FIG. 3. Brush Creek Island Habitats. Vegetated Unconsolidated Shoreline (US) perimeter habitat to Bottomland Hardwood Forest (BHF) habitat adapted by Melanie Givan from Google Earth Pro 2016 image.

3). Probable disappearing canopy relics of an earlier sere of shade-intolerant trees were: Platanus occidentalis, Populus deltoides, Juglans nigra, and Robinia pseudoacacia. These four native canopy trees and two exotics, Morus alba and Ailanthus altissima, were not regenerating well in the seedling, sapling, and small tree classes (Table 3). Unsuccessful invaders comprised the remaining understory and overstory trees: Prunus serotina, Fraxinus pennsylvanica, Catalpa speciosa, Betula nigra, Liriodendron tulipifera, Acer saccharum, Cornus florida, and Frangula caroliniana (Table 3).

\section{ANNOTATED LIST OF VASCULAR PLANTS}

The following features were assessed for each taxon: (o) Lewis County distribution records (Campbell \& Medley 2006, 2012); (*) non-native plant origin (Weakley 2020; USDA, NRCS 2021); (**) invasive species status (KY-EPPC 2013); habitat(s) of occurrence; inclusive relative abundance value (Thompson \& Rivers Thompson 2016); national wetland indicator status (Lichvar 2013); and italicized voucher specimen number(s), e.g., BC-39, BC-1519.

Wetland plant habitats adapted from Tolin and Schettig (1983) include Vegetated Unconsolidated Shoreline (US), Riverine Emergent Wetland (REW), Late Old Field (LO), and both Immature Bottomland Forest (IB) and Mature Bottomland Forest (MB), as BHF.

A relative abundance scale of categories inclusive for each taxon from all plant habitats is derived from Thompson and Rivers Thompson (2016): R (Rare)=1 to 4 plants or colonies, very difficult to find in one or two locations; S (Scarce) $=5$ to 10 plants or colonies, difficult to find in a few locations; I (Infrequent) $=11$ to 30 plants or colonies, uncommon, scattered in some locations; O (Occasional) $=31$ to 100 plants or colonies, widely scattered in several locations; F (Frequent)=101 to 1000 plants or colonies, common, easily found in 


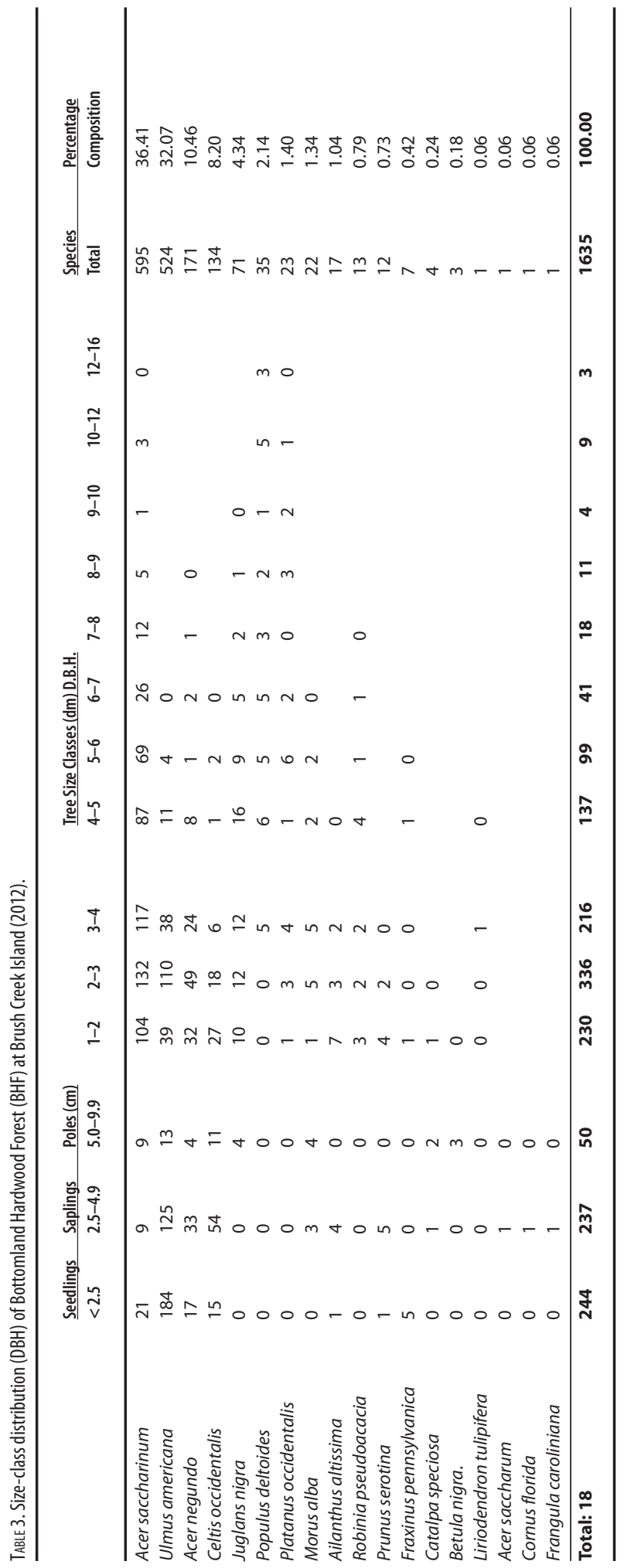


numerous locations; and A (Abundant)=>1000 plants or colonies, diagnostic or dominant species throughout many locations.

Five NWPL indicator categories are: Obligate (OBL)—hydrophytes almost always occurring in wetlands; Facultative Wetland (FACW) — hydrophytes usually occurring in wetlands; and, Facultative (FAC) hydrophytes occurring in wetlands and non-wetlands. Non-wetland indicator categories are: Facultative Upland (FACU) —non-hydrophytes usually occurring in non-wetlands, and Upland (UPL) —non-hydrophytes almost never occurring in wetlands (Lichvar 2013). Not Included (NI) rating is designated for plants not currently classified by the National and Regional Panel (Lichvar 2013).

\section{MONILOPHYTA}

\section{Equisetaceae}

Equisetum arvense L. (Field Horsetail). US, REW; A; FAC. BC-39, BC-1519

\section{MAGNOLIIDS AND PRIMITIVE ANGIOSPERMS}

\section{Annonaceae}

Asimina triloba (L.) Dunal (Common Pawpaw). BHF; I; FAC. BC-182

\section{Lauraceae}

Lindera benzoin (L.) Blume (Northern Spicebush). BHF; I; FAC. BC-458

Sassafras albidum (Nutt.) Nees (Sassafras). BHF; S; FACU. BC-176

\section{Magnoliaceae}

Liriodendron tulipifera L. var. tulipifera (Tulip-Tree). BHF; R; FACU. BC- 50, BC- 174

\section{MONOCOTYLEDONAE (MONOCOTS)}

\section{Alismataceae}

Alisma subcordatum Raf. (Southern Water-Plantain). REW; S; OBL. BC-1308

Sagittaria calycina Engelm. (Mississippi Arrowhead). REW; R; OBL. BC-1007

\section{Alliaceae}

oAllium canadense L. (Wild Onion). LO; I; FACU. BC-450

${ }^{* *}$ Allium vineale L. (Field Garlic). LO; O; FACU. BC-431

\section{Commelinaceae}

O**Commelina communis L. (Asiatic Dayflower). US, LO; I; FAC. BC-1006

Commelina virginica L. (Virginia Dayflower). US; S; FACW. BC-1061

\section{Cyperaceae}

Carex blanda Dewey (Eastern Woodland Sedge). LO, BHF; F; FAC. BC-161

oCarex davisii Schwein. \& Torr. (Davis's Sedge). BHF; S; FAC. BC-164

Carex frankii Kunth (Frank's Sedge). REW; S; OBL. BC-413

oCarex grayi Carey (Gray's Sedge). BHF; F; FACW. BC-162

oCarex grisea Wahlenb. (Inflated Narrowleaf Sedge). LO, BHF; F; FAC. BC-163

Carex tribuloides Wahlenb. (Blunt Broom Sedge). REW; S; FACW. BC-412, BC-1277

oCarex vulpinoidea Michx. (Fox Sedge). REW, R; OBL. BC-415

oCyperus bipartitus Torr. (Shining Flatsedge). US, REW; O; FACW. BC-1126

*Cyperus brevifolioides Thieret \& Delchousaye (Asiatic Greenhead Sedge). US, REW; I; FACW. BC-1305, BC-1506

Cyperus erythrorhizos Muhl. (Redroot Flatsedge). REW; O; FACW. BC-611, BC-1511

oCyperus esculentus L. (Yellow Nutsedge). REW; O; FACW. BC-1008 Cyperus flavescens L. (Yellow Flatsedge). US; S; OBL. BC-1504

Cyperus odoratus L. var. odoratus (Fragrant Flatsedge). US, REW; I; FACW. BC-1083

oCyperus squarrosus L. (Awned Flatsedge). US; I; FACW. BC-1018

Cyperus strigosus L. (False Nutsedge). US, REW; O; FACW. BC-612, BC-1055

oEleocharis erythropoda Steud. (Bald Spikerush). REW; R; OBL. BC-604
Eleocharis obtusa (Willd.) J.A. Schultes (Blunt Spikerush). REW; l; OBL. BC-1313

oFimbristylis autumnalis (L.) Roemer \& Schultes (Slender Fimbry). US, REW; O; FACW. BC-1046, BC-1532

Schoenoplectus tabernaemontani (C.C. Gmel.) Palla (Softstem Bulrush). REW; R; OBL. BC-605

\section{Hemerocallidaceae}

**Hemerocallis fulva (L.) L. (Orange Day-Lily). LO; S; FACU. BC-1276

\section{Hyacinthaceae}

**Ornithogalum umbellatum L. (Star-of-Bethlehem). LO; I; FACU. $B C-1185$

\section{Hydrocharitaceae}

Vallisneria americana Michx. (Eelgrass). US; I. OBL. BC-1000

\section{Juncaceae}

Juncus acuminatus Michx. (Sharpfruit Rush). REW; O; OBL. BC-608 Juncus effusus L. ssp. solutus (Fernald \& Wiegand) Hämet-Ahti (Soft Rush). REW; O; FACW. BC-422

oJuncus interior Wiegand (Inland Rush). REW; S; FAC. BC-263

Juncus tenuis Willd. (Slender Path Rush). US, REW; I; FACU. BC-1558

\section{Liliaceae}

Erythronium americanum Ker-Gawl. ssp. americanum (Yellow TroutLily). BHF; I; FACU. BC-45

\section{Poaceae}

${ }^{*}$ Agrostis gigantea Roth (Redtop). LO; S; FACW. BC-827

Agrostis perennans (Walter) Tuckerm. (Upland Bent). LO; S; FACU. $B C-1078$

**Arthraxon hispidus (Thunb.) Makino var. hispidus (Basket Grass). US; F; FAC. BC-1100, BC-1525

Bromus latiglumis (Shear) A.S.Hitchc. (Riverbank Brome). BHF; I; FACW. BC-1560

Chasmanthium latifolium (Michx.) Yates (River Oats). BHF; O; FACU. $B C-1528$

Cinna arundinacea L. (Common Woodreed). LO, BHF; O; FACW. $B C-569$

Dichanthelium clandestinum (L.) Gould (Deer-Tongue Panicum). LO; O; FAC. BC-570 
oDigitaria ciliaris (Retz.) Köeler (Southern Crab-Grass). US; I. FAC. $B C-576$

*Digitaria ischaemum (Schreb.) Muhl. (Smooth Crab-Grass). US; I; UPL. BC-1042

O*Digitaria sanguinalis (L.) Scopoli (Northern Crab-Grass). US; F; FACU. BC-821, BC-1494

oDinebra panicea (Retz.) P.M. Peterson \& N. Snow ssp. brachiata (Steud.) P.M. Peterson \& N. Snow (Red Spangletop). US; S; NI. $B C-1311$.

O**Echinochloa crusgalli (L.) P. Beauv. var crusgalli (Common Barnyard-Grass). US; F; FAC. BC-577, BC-803

oEchinochloa muricata (P. Beauv.) Fernald var. muricata (Rough Barnyard-Grass). US; O; FACW. BC-823, BC-1524

**Eleusine indica (L.) Gaertn. (Yard Grass). US; O; FACU. BC-575, BC-1556

oElymus macgregorii R.E. Brooks \& J.J.N. Campb. (Early Wild-Rye). BHF; O; NI. BC-1287

oElymus virginicus L. (Virginia Wild-Rye). LO, BHF; F; FACW. BC-426, BC 1285

O**Eragrostis cilianensis (All.) Vign. ex Janc. (Stinkgrass). US; S; FACU. BC-558

oEragrostis frankii C.A. Meyer ex Steud. (Sandbar Lovegrass). US; I; FACW. BC-1315

Eragrostis hypnoides (Lam.) B.S.P. (Creeping Lovegrass). US; A; OBL. BC-567

Eragrostis pectinacea (Michx.) Nees ex Steud. var. pectinacea (Carolina Lovegrass). US; F; FAC. BC-565, BC-1512

Festuca subverticillata (Pers.) E. Alexeev. (Nodding Fescue). BHF; I; FACU. BC-165, BC-245

Glyceria striata (Lam.) A.S. Hitchc. var. striata (Fowl Mannagrass). REW; O; OBL. BC-288

Leersia oryzoides (L.) Swartz (Rice Cutgrass). REW; O; OBL. BC-421

Leersia virginica Willd. (White Cutgrass). BHF; A; FAC. BC-573, BC-1549

\section{EUDICOTYLEDONAE (EUDICOTS)}

\section{Acanthaceae}

Justicia americana (L.) M. Vahl (American Water-Willow). US, REM; S; OBL. BC-239

\section{Aceraceae}

Acer negundo L. var. negundo (Eastern Box-Elder). BHF; A; FAC. BC-296; BC-1563

Acer saccharinum L. (Silver Maple). US, BHF; A; FACW. BC-49, BC-820 oAcer saccharum Marsh. var. saccharum (Sugar Maple). BHF; S; FACU. BC-1192

\section{Amaranthaceae}

$\mathrm{O}^{* *}$ Achyranthes japonica (Miq.) Nakai. var. hachjoensis Honda (Japanese Chaff-Flower). LO, BHF; A; NI. BC-1077, BC-1553

${ }^{*}$ Amaranthus albus L. (Tumbleweed Amaranth). US; R; FACU. BC-1499

*Amaranthus hybridus L. ssp. hybridus (Smooth Amaranth). US; O; NI. BC-1490

*Amaranthus spinosus L. (Spiny Amaranth). US; F; FACU. BC-545

Amaranthus tuberculatus (Moquin-Tandon) J.D. Sauer (Inland Water-Hemp). US; O; FACW. BC-825, BC-1508

\section{Anacardiaceae}

Rhus typhina L. (Staghorn Sumac). LO; S; NI. BC-798

oToxicodendron radicans (L.) Kuntze (Midwestern Poison-Ivy). LO, BHF; A; FAC. BC-66

\section{Apiaceae}

Chaerophyllum procumbens (L.) Crantz. var. procumbens (Common Spreading Chervil). LO; O; FACW. BC-1186
O**Lolium arundinaceum (Schreb.) Darbyshire (Tall Fescue). LO; I; FACU. BC-420

**Microstegium vimineum (Trin.) A. Camus (Japanese Stilt-Grass). BHF; A; FAC. BC-1107

Muhlenbergia frondosa (Poir.) Fernald (Satin-Grass Muhly). BHF; F; FAC. BC-1541

Panicum capillare L. (Old Witch-Grass). US; F; FAC. BC-809, BC-1526

Panicum dichotomiflorum Michx. var. dichotomiflorum (Fall Panic Grass). US; REW; F; FACW. BC-808, BC-1492

Panicum virgatum $L$. var. virgatum (Switchgrass). LO; l; FAC. BC-579 oPaspalum fluitans (Ell.) Kunth (Mudflat Beadgrass). US; O; OBL. BC-822, BC-1516

Phalaris arundinacea L. (Reed Canary-Grass). LO; O; FACW. BC-169 oPoa alsodes A. Gray (Woodland Bluegrass). BHF; R; FAC. BC-1195

**Poa pratensis L. ssp. pratensis (Kentucky Bluegrass). LO; O; FACU. $B C-166, B C-1198$

*Poa trivialis L. ssp. trivialis (Rough Bluegrass). LO; R; FACW. BC-170

**Setaria faberi R.A.W. Herrm. (Nodding Foxtail). US; I; UPL. BC-566

*Setaria pumila (Poir.) Roemer \& J.A. Schultes (Yellow Foxtail). US; I; FAC. BC-574

**Sorghum halepense (L.) Pers. (Johnson Grass). US, LO; O; FACU. BC- $445, B C-1520$

Sphenopholis intermedia (Rydb.) Rydb. (Slender Wedgegrass). LO; O; FAC. BC-168

Tridens flavus (L.) A.S. Hitchc. (Purpletop). LO; I; FACU. BC-1125

O*Triticum aestivum L. (Common Wheat). US; R; NI. BC-167

\section{Ruscaceae}

Polygonatum biflorum (Walter) Ell. var. biflorum (Small Solomon'sSeal). BHF; R; FACU. BC-1184

\section{Smilaceaceae}

Smilax hispida Raf. var, hispida (Bristly Greenbrier). LO; S; FAC. BC-300, BC-444

Cicuta maculata L. var. maculata (Water-Hemlock). REW; R; OBL. BC-1282

Cryptotaenia canadensis (L.) DC. (Canada Honewort). BHF; F; FAC. BC-188, BC-248

**Daucus carota L. ssp. carota (Queen-Anne's-Lace). LO; I; UPL. BC-291

oHeracleum maximum W. Bartr. (Cow-Parship). LO; R; FAC. BC-254

Osmorhiza longistylis (Torr.) A.P. DC. (Smooth Sweet Cicely). LO, BHF; O; FACU. BC-1190

\section{Apocynaceae}

Apocynum cannabinum L. (Indian-Hemp). LO; I; FACU. BC-307

Asclepias incarnata L. (Western Swamp Milkweed). REW; S; OBL. BC-455

Asclepias syriaca L. (Common Milkweed). LO; O; FACU. BC-306, BC-796

oCynanchum laeve (Michx.) Pers. (Honeyvine). US, LO; O; NI. BC-560

\section{Asteraceae}

Ageratina altissima (L.) R.M. King \& H. Rob. (White Snakeroot). BHF; F; FACU. BC-1537

Ambrosia artemisiifolia L. (Common Ragweed). US; O; FACU. BC-556 Ambrosia trifida L. var. trifida (Giant Ragweed). LO; I.; FAC. BC-1028 ${ }^{*}$ Artemisia annua L. (Annual Mugwort). US; O; FACU. BC-998

$\mathrm{O}^{* *}$ Artemisia vulgaris L. (Common Mugwort). US; F; UPL. BC-539, BC-1496

oBidens cernua L. (Nodding Bur-Marigold). US; REW; O; OBL. BC-1108 oBidens comosa (A. Gray) Wiegand (Strawberry Beggars-Ticks). US; I; FACW. BC-1109 
Bidens frondosa L. (Devil's Beggar-Ticks). US; O; FACW. BC-1040 Bidens polylepis S.F. Blake (Bearded Beggar-Ticks). US; O; NI. BC1002, BC-1502

Bidens vulgata Greene (Tall Beggar-Ticks). US, REW; I; FACW. BC-1119 ${ }^{* *}$ Cirsium arvense (L.) Scop. (Canada Thistle). US, LO; I; FACU. BC-304 Conoclinium coelestinum (L.) DC. (Blue Mistflower). LO; I; FAC. BC-817, BC-1535

O*Eclipta prostrata (L.) L. (Yerba-de-Tajo). US; O; FACW. BC-586, BC-1503

oErechtites hieraciifolius (L.) Raf. ex DC. (American Fireweed). US; I; NI. BC-1034

Erigeron annuus (L.) Pers. (Annual Fleabane). LO; O; FACU. BC-262

Erigeron canadensis L. (Common Horseweed). US, LO; I; FACU. BC-587

Erigeron philadelphicus L. (Philadelphia-Daisy). LO; O; FACU. BC-178 Eupatorium perfoliatum L. (Common Boneset). LO; O; FACW. BC-585 Eupatorium serotinum Michx. (Late Boneset). LO; F; FAC. BC-1033

Eurybia divaricata (L.) G.L. Nesom (White Heartleaf Wood Aster). LO, BHF; F; NI. BC-1004

Euthamia graminifolia (L.) Nutt. (Grassleaf Goldenrod). LO, BHF; O; FAC. BC-537

Eutrochium fistulosum (Barratt) E.E. Lamont (Hollowstem Joe-PyeWeed). LO; O; FACW. BC-583

*Galinsoga quadriradiata Ruiz \& Pavón (Common Peruvian-Daisy). US; l; FACU. BC-1517

Gnaphalium uliginosum L. (Marsh Cudweed). US; R; FAC. BC-1288

Helenium autumnale L. (Common Sneezeweed). US, REW; I; FACW. BC-1059

Helianthus decapetalus L. (Forest Sunflower). BHF; I; FACU. BC-818, BC-1542

Helianthus tuberosus L. (Jerusalem Artichoke). LO, BHF; O; FACU. $B C-1060, B C-1543$

oLactuca biennis (Moench) Fernald (Tall Blue Lettuce). LO; I; FACU. BC-806

Lactuca floridana (L.) Gaertn. (Woodland Blue Lettuce). LO; R; FACU. BC-815, BC-1032

Packera aurea (L.) A. Löve \& D. Löve (Golden Ragwort). BHF; I; FACW. BC-1194

Rudbeckia laciniata L. var. laciniata (Common Cutleaf Coneflower). LO, BHF; A; FACW. BC-540

oSenecio suaveolens (L.) Ell. (Sweet Indian-Plantain). LO, BHF; O; FACW. BC-1548

oSilphium perfoliatum L. (Common Cup-Plant). LO; I; FAC. BC-440, BC-797

Solidago altissima L. var. altissima (Tall Goldenrod). LO; O; FACU. BC-1544

oSolidago gigantea Aiton (Smooth Goldenrod). OF, BHF; F; FACW. $B C-581, B C-1066$

**Sonchus asper (L.) Hill (Spinyleaf Sow-Thistle). US; I; FAC. BC-261

oSymphyotrichum lateriflorum (L.) A. Löve \& D. Löve (Goblet Aster). LO, BHF; I; FACW. BC-1122, BC-1538

Symphyotrichum ontarionis (Wieg.) G.L. Nesom, var. ontarionis (Bottomland Aster). BHF; I; FAC. BC-1123

Symphyotrichum pilosum (Willd.) G.L. Nesom var. pilosum (Hairy White Old-Field Aster). LO; O; FAC. BC-1036, BC-1120

Symphyotrichum prenanthoides (Muhl. ex Willd.) G.L. Nesom (ZigZag Aster). BHF; I; FAC. BC-1030, BC-1112

*Taraxacum officinale G.H. Weber ex Wiggers (Common Dandelion). US; O; FACU. BC-40

O**Tussilago farfara L., Coltsfoot. LO; R; FACU. BC-43

Verbesina alternifolia (L.) Britton ex Kearney (Common Wingstem). LO, BHF; A; FAC. BC-582

oVerbesina occidentalis (L.) Walter (Southern Crownbeard). LO; I; FACU. BC-1113
Vernonia gigantea (Walter) Banner \& Coville (Giant Ironweed). LO; I; FAC. BC-538

Xanthium chinense P. Mill. (Rough Cocklebur). US; O; FAC. BC-1063

\section{Balsaminaceae}

Impatiens capensis Meerb. (Orange Jewelweed). LO, BHF; I; FACW. BC-429

Impatiens pallida Nutt. (Yellow Jewelweed). BHF; F; FACW. BC-289

Betulaceae

Betula nigra L. (River Birch). US, BHF; I; FACW. BC-52, BC-268

\section{Bignoniaceae}

Campsis radicans (L.) Seem. ex Bureau (Trumpet-Creeper). LO, BHF; F; FAC. BC-453

oCatalpa speciosa Warder ex Engelm. (Northern Catalpa). BHF; S; FAC. BC-1534

\section{Boraginaceae}

Hackelia virginiana (L.) I.M. Johnst. (Virginia Stickseed). LO; O; FACU. BC-541

oMyosotis macrosperma Engelm. (Bigseed Scorpion-Grass). LO; I; FAC. BC-1183

O*Myosotis scorpioides L. (Water Scorpion-Grass). US; O; OBL. $B C-457, B C-1281$

\section{Brassicaceae}

O**Alliaria petiolata (M. Bieb.) Cavara \& Grande (Garlic Mustard). LO, BHF; A; FACU. BC-1547

**Barbarea vulgaris W. Aiton (Yellow Rocket). US, LO; I; FACU. BC-177 *Brassica nigra (L.) W.D.J. Koch (Black Mustard). US, LO; I; UPL. BC-552

*Capsella bursa-pastoris (L.) Medik. (Shepherd's Purse). US, LO; S; FACU. BC-235

O*Cardamine hirsuta L. (Hairy Bittercress). US, LO; A; FACU. BC-57

$\mathrm{O}^{*}$ Cardamine impatiens L. (Narrowleaf Bittercress). LO, BHF; F; FAC. BC-189, BC-259

Cardamine pensylvanica Muhl. ex Willd. (Quaker Bittercress). US; LO; S; OBL. BC-1278

O**Hesperis matronalis L. (Dame's Rocket). LO, BHF; O; FACU. BC-1188

oLepidium virginicum L. var. virginicum (Poor Man's Pepper). US; S; FACU. BC-1309

Rorippa palustris (L.) Besser ssp. palustris (Yellow Marsh Cress). US; O; FACW. BC-1523

${ }^{*}$ Rorippa sylvestris (L.) Besser (Creeping Yellow Cress). US; I; FACW. $B C-275$

\section{Campanulaceae}

Campanulastrum americanum (L.) Small (American Bellflower). LO; S; FACU. BC-588

Lobelia cardinalis L. var. cardinalis (Cardinal Flower). US; R; FACW. BC-589

Lobelia inflata L. (Indian-Tobacco). US, LO; I; FACU. BC-591

Lobelia siphilitica L. (Great Blue Lobelia). LO; S; FACW. BC-811, BC-1552

Triodanis perfoliata (L.) Nieuwl. (Venus's Looking-Glass). LO; O; FAC. BC-160

\section{Cannabaceae}

O*Cannabis sativa L. (Common Hemp). US; R; NI. BC-601, BC-1111 Celtis occidentalis L. (Northern Hackberry). BHF; F; FACU. BC-44

O**Humulus japonicus Sieb. \& Zucc. (Japanese Hops). LO; O; FACU. BC-1303

\section{Caprifoliaceae}

**Lonicera japonica Thunb. (Japanese Honeysuckle). LO, BHF; F; FAC. BC-53, BC-298

O**Lonicera maackii (Rupr.) Herder (Amur Honeysuckle). BHF; O; NI. $B C-1189$ 


\section{Caryophyllaceae}

*Cerastium glomeratum Thuill. (Sticky Mouse-Ear Chickweed). LO; I; UPL. BC-65

*Stellaria aquaticum (L.) Scop. (Water-Chickweed). LO, REW; F; FACW. BC-184, BC 805

**Stellaria media (L.) Villars (Common Chickweed). LO, BHF; A; UPL. BC-59

\section{Celastraceae}

O**Celastrus orbiculatus Thunb. (Oriental Bittersweet). LO, BHF; I; FACU. BC-449

Euonymus atropurpureus Jacq. (American Wahoo). BHF; R; FACU. $B C-434$

\section{Chenopodiaceae}

Chenopodium album L. (Lamb's-Quarters). US; O; FACU. BC-260, BC-1513

oDysphania ambrosioides (L.) Mosyakin \& Clemants (Mexican-Tea). US; A; FACU. BC-1507

O*Dysphania botrys (L.) Mosyakin \& Clemants (Jerusalem-Oak). US; S; UPL. BC-1555

\section{Cleomaceae}

O*Tarenaya hassleriana (Chodat) H.H. Iltis (Spiderflower). US; R; FAC. BC-804

\section{Convolvulaceae}

Convolvulus sepium L. (Hedge-Bindweed). LO; I; FAC. BC-427, $B C-1510$

oCuscuta gronovii Willd. ex Roemer \& J.A. Schultes (Common Dodder). LO; S; NI. BC-1102

**Ipomoea hederacea Jacq. (Ivyleaf Morning-Glory). US; S; FACU. $B C-1081$

olpomoea lacunosa L. (Small White Morning-Glory). US; O; FACW. $B C-800$

**Ipomoea purpurea (L.) Roth (Common Morning-Glory). US; S; UPL. BC-1501

\section{Cornaceae}

oCornus amomum P. Mill. (Silky Dogwood). US, LO; S; FACW. BC285, BC-1076

Cornus florida L. Spach. (Flowering Dogwood). BHF; S; FACU. BC-452

\section{Cucurbitaceae}

*Citrullus lanatus (Thunb.) Matsum. \& Nakai (Watermelon). US; R; UPL. BC-1039

O*Cucurbita pepo L. (Ornamental Thinshell Gourd). US; R, NI. $B C-1527$

Sicyos angulatus L. (Bur-Cucumber). LO; S; FACW. BC-1022, BC-1545

\section{Euphorbiaceae}

Acalypha rhomboidea Raf. (Rhombic Copperleaf). US; F; FACU. BC-1117

oEuphorbia humistrata Engelm. ex A. Gray (Spreading Sandmat). US; S; FAC. BC-1041

oEuphorbia maculata L. (Spotted Sandmat). US; F; FACU. BC-1500 Euphorbia nutans Lagasca \& Segura (Eyebane Spurge). US; O; FACU. BC-824

\section{Fabaceae}

oAmorpha fruticosa L. (Tall Indigo Bush). US, LO; O; FACW. BC-592 Amphicarpaea bracteata (L.) Fernald var. bracteata (Hog-Peanut). LO; F; FAC. BC-1105

oApios americana Medik. (Common Groundnut). LO, BHF; I; FACW. BC-997

oDesmodium glabellum (Michx.) DC. (Dillenius' Tick-Trefoil). LO; S; FACU. BC-1062

**Lespedeza cuneata (Dum.-Cours.) G. Don. (Sericea Lespedeza). LO; I; FACU. BC-1031
**Melilotus officinalis (L.) Pallas (Yellow Sweetclover). US; I; UPL. $B C-302$

Robinia pseudoacacia L. (Black Locust). BHF O; FACU. BC-41

Strophostyles helvola (L.) Ell. (Annual Sand Bean). US, LO; F; FACU. BC-1531

**Trifolium repens L. (White Clover). US; I; FACU. BC-179

\section{Fumariaceae}

Corydalis flavula (Raf.) DC. (Yellow Fumewort). BHF; F; FACU. BC-63

\section{Geraniaceae}

Geranium carolinianum L. (Carolina Crane's-Bill). LO; O; NI. BC-190

\section{Hyperiaceae}

Hypericum mutilum L. var. mutilum (Dwarf St. John's-Wort). US, REW; O; FACW. BC-542

oHypericum prolificum L. (Shrubby St. John's-Wort). LO; R; FACU. $B C-171, B C-1075$

Hypericum punctatum Lam. (Spotted St. John's-Wort). LO; S; FAC. BC-999

\section{Juglandaceae}

Juglans nigra L. (Black Walnut). BHF; F; FACU. BC-256

\section{Lamiaceae}

oAgastache nepetoides (L.) Kuntze (Yellow Giant-Hyssop). LO; R; FACU. BC-1011

Blephilia hirsuta (Pursh) Bentham (Hairy Woodmint). BHF; R; NI. BC-430

**Glechoma hederacea L. (Ground-Ivy). LO, BHF; A; FACU. BC-55

**Lamium purpureum L. (Red Dead-Nettle). LO; A; NI. BC-61

Lycopus americanus Muhl. ex W. Barton (American Bugleweed). REW; S; OBL. BC-1522

Lycopus virginicus L. (Virginia Bugleweed). REW; S; OBL. BC-1101

Monarda fistulosa L. var. mollis (L.) Bentham (Wild Bergamot). LO; I; UPL. BC-1284

O**Perilla frutescens (L.) Britton (India Perilla). US, LO; I; FACU. BC-1114

Prunella vulgaris L. (Self-Heal). LO; R; FACU. BC-562

Scutellaria lateriflora L. (Mad-Dog Skullcap). REW; I; FACW. BC-546

Stachys tenuifolia Willd. (Smooth Hedge-Nettle). LO; S; FACW. BC-443; BC-547

Teucrium canadense L. var. canadense (Common Germander). LO; O; FACW. BC-439

\section{Limnanthaceae}

oFloerkea proserpinacoides Willd. (False-Mermaid). LO, BHF; A; FAC. $B C-280, B C-1193$

\section{Linderniaceae}

Lindernia dubia (L.) Pennell (Yellowseed False-Pimpernel). US; F; OBL. BC-1518

\section{Lythraceae}

Ammannia coccinea Rottb. (Eared Redstem). US, REW; I; OBL. BC1037, BC-1509

**Lythrum salicaria L. (Purple Loosestrife). US; I; FACW. BC-606

\section{Malvaceae}

O*Abutilon theophrasti Medik. (Velvetleaf). US; I; FACU. BC-131; BC-1565

Hibiscus moscheutos L. (Eastern Rose-Mallow). US; R; OBL. BC-812 oRipariosida hermaphrodita (L.) Weakley \& Poindexter (VirginiaSida). LO; S; FAC. BC 1125

*Sida spinosa L. (Prickly Sida). US; O; UPL. BC-1045

\section{Mazaceae}

O*Mazus pumilus (Berm. f.) Stennis (Japanese Mazus). US; I; FACU. BC-1498 


\section{Menispermaceae}

Menispermum canadense L. (Canada Moonseed). BHF; O; FACU. BC-172

\section{Molluginaceae}

O*Mollugo verticillata L. (Carpetweed). US; F; FAC. BC-424, BC-1497

\section{Montiaceae}

Claytonia virginica L. var. virginica (Eastern Spring Beauty). BHF; I; FAC. BC-58

\section{Moraceae}

O**Morus alba L. (White Mulberry). BHF; O; FACU. BC-47, BC-175

\section{Oleaceae}

Fraxinus pennsylvanica Marsh. (Green Ash). BHF; S; FACW. BC-462 $\mathrm{O}^{* *}$ Ligustrum sinense Lour. (Chinese Privet). LO; R; FACU. BC-283, BC-12z83

\section{Onagraceae}

Ludwigia alternifolia L. (Alternateleaf Seedbox). US, REW; S; FACW. BC-1048

Ludwigia decurrens Walter (Wingstem Water-Primrose). REW; O; OBL. BC-1044

Ludwigia leptocarpa (Nutt.) H. Hara (Water-Willow). REW; R; OBL. $B C-1116$

Ludwigia palustris (L.) Ell. (Common Water-Purslane). US, REW; F; OBL. BC-1491

Oenothera biennis L. (Common Evening-Primrose). LO; O; FACU. BC-602, BC-1493

\section{Oxalidaceae}

Oxalis dillenii Jacq. (Southern Yellow Wood-Sorrel). US, LO; O; FACU. BC-273

Oxalis stricta L. (Common Yellow Wood-Sorrel). US,LO; O; FACU. $B C-428, B C-1050$

\section{Paulowniaceae}

o**Paulownia tomentosa (Thunb.) Sieb. \& Zucc. ex Steud. (Chinese Empress Tree). BHF; R; UPL. BC-1551

\section{Penthoraceae}

Penthorum sedoides L. (American Ditch-Stonecrop). US, REW; O; OBL. BC-563

\section{Phrymaceae}

Mimulus alatus Aiton (Winged Monkey-Flower). REW; R; OBL. BC-435

Mimulus ringens L. var. ringens (Allegheny Monkey-Flower). REW; I; OBL. BC-436

\section{Phytolacaceae}

Phytolacca americana L. (Common Pokeweed). US, LO; O; FACU. $B C-272$

\section{Plantaginaceae}

Leucospora multifida (Michx.) Nutt. (Narrowleaf Paleseed). US; O; OBL. BC-1279; BC-1568

* Linaria vulgaris P. Mill. (Yellow Toadflax). US; R; NI. BC-1024;BC-1562

*Plantago lanceolata L. (English Plantain). US, LO; O; UPL. BC-267

Plantago rugelii Decne. (Rugel's Plantain). US; O; FACU. BC-270

*Veronica arvensis L. (Corn Speedwell). LO; I; UPL. BC-188

Veronica peregrina L. var. peregrina (Purslane Speedwell). US, REW; l; FAC. BC-258

\section{Platanaceae}

Platanus occidentalis L. (American Sycamore). LO, BHF; F; FACW. BC-293

\section{Polemoniaceae}

Phlox paniculata L. (Summer Phlox). BHF; S; FACU. BC-555, BC-1035

\section{Polygonaceae}

Fallopia scandens (L.) Holub (Climbing Buckwheat). LO, BHF; F; FAC. BC-1550

Persicaria lapathifolia (L.) S.F. Gray (Dockleaf Smartweed). US, REW; O; FACW. BC-1495

**Persicaria longiseta (de Bruijn) Kitagawa, (Longbristle Asiatic Smartweed). US, REW; F; FAC. BC-596

**Persicaria maculosa S.F. Gray (Heart's-Ease). US; O; FACW. BC-593

Persicaria pensylvanica (L.) M. Gómez (Pennsylvania Smartweed). US, REW; O; FACW. BC-1054, BC-1521

Persicaria punctata (Ell.) Small (Dotted Smartweed). US, REW; O; OBL. BC-1070

Persicaria virginiana (L.) Gaertn. (Virginia Knotweed). BHF; F; FAC. BC-597

*Polygonum aviculare L. (Dooryard Knotweed). US; S; FAC. BC-1314

**Reynoutria japonica Houtt. (Japanese Knotweed). LO, BHF; A; FACU. BC-69, BC-1559

${ }^{*}$ Rumex crispus L. ssp. crispus (Curly Dock). US, LO; O; FAC. BC-180

*Rumex obtusifolius L., (Bitter Dock). US, LO; O; FACU. BC-463, $B C-1027$

${ }^{*}$ Rumex patientia L. (Monk's Rhubarb). US; I; NI. BC-417

\section{Portulacaceae}

O*Portulaca oleracea L. (Common Purslane). US; O; FAC. BC-1280, BC-1514

\section{Primulaceae}

**Lysimachia nummularia L. (Creeping Jenny). US; REW; O; FACW. BC-183

Samolus parviflorus Raf. (Water-Pimpernal). REW; R; OBL. BC-1120

Steironema ciliatum (L.) Baude (Fringed Loosestrife). BHF; S; FACW. $B C-441$

\section{Ranunculaceae}

Clematis virginiana L. (Virgin's-Bower). LO; O; FAC. BC-446

$\mathrm{O}^{* *}$ Filicaria verna Huds. ssp. calthifolia (Reich.) Nyman. (Lesser Celadine). BHF; I; FAC. BC-51

Ranunculus abortivus L. (Kidneyleaf Crowfoot). LO, BHF; O; FACW. $B C-64$

Ranunculus recurvatus Poir. var. recurvatus (Hooked Buttercup). BHF; S; FAC. BC-1196

O*Ranunculus repens L. (Creeping Buttercup). US; I; FAC. BC-247

${ }^{*}$ Ranunculus sceleratus L. var. sceleratus (Celeryleaf Crowfoot). REW; $\mathrm{R}$; OBL. BC-1306

Thalictrum pubescens Pursh (Late Meadowrue). BHF; O; FACW. $B C-185, B C-432$

\section{Rhamnaceae}

Frangula caroliniana (Walter) A. Gray (Carolina Buckthorn). LO, BHS; R; FAC. BC-253

\section{Rosaceae}

Geum canadense Jacq. (White Avens). BHF; O; FACU. BC-460

oPhysocarpus opulifolius (L.) Maxim. (Eastern Ninebark). LO; R; FACW. BC-1187

$\mathrm{O}^{* *}$ Potentilla indica (Andrews) T. Wolf (India Strawberry). LO; F; FACU. BC-191

Potentilla norvegica L. (Rough Cinquefoil). BHF; I; FACU. BC-249

Prunus serotina Ehrh. var. serotina (Eastern Wild Black Cherry). LO, BHF; O; FACU. BC-68

**Rosa multiflora Thunb. ex Murr. (Multiflora Rose). LO; O; FACU. $B C-600$

Rubus occidentalis L. (Black Raspberry). LO; F; NI. BC-67, BC-295

oRubus pensilvanicus Poir. (Eastern Blackberry). LO; F; FAC. BC-257

\section{Rubiaceae}

Cephalanthus occidentalis L. (Buttonbush). REW; S; OBL. BC-1047 
Diodia virginiana L. (Large Buttonweed). US, REW; F; FACW. BC-418 Galium aparine L. (Common Cleavers). LO; BHF; A; FACU. BC-265

Galium triflorum Michx. (Fragrant Bedstraw). BHF; I; FACU. BC-614

Spermacoce glabra Michx. (Smooth Buttonweed). REW; R; FACW. $B C-1053$

\section{Rutaceae}

Ptelea trifoliata L. (Common Hop-Tree). BHF; R; FAC. BC-451

\section{Salicaceae}

Populus deltoides Bartr. ex Marsh. ssp. deltoides (Eastern Cottonwood). US, BHF; F; FAC. BC-46

Salix interior Rowlee (Sandbar Willow). US; F; FACW. BC-557

Salix nigra Marsh. (Black Willow). US; F; OBL. BC- 536; BC-1564

\section{Scrophulariaceae}

Scrophularia marilandica L. (Eastern Figwort). LO; O; FACU. BC-551, BC-1539

O*Verbascum blattaria L. (Moth Mullein). US; I; UPL. BC-181, BC-242

**Verbascum thapsus L. ssp. thapsus (Woolly Mullein). US; O; FACU. $B C-305, B C-1557$

\section{Simaroubaceae}

**Ailanthus altissima (P. Mill.) Swingle (Tree-of-Heaven). BHF; I; FACU. BC-241; BC-1566

\section{Solanaceae}

*Datura stramonium L. (Jimson-Weed). US; F; NI. BC-438; BC-1561

oPhysalis heterophylla Nees (Clammy Ground-Cherry). US; I; NI. BC-187

Physalis longifolia Nutt. var. subglabrata (Mack. \& Bush) Cronq. (Longleaf Ground-Cherry). US; I; UPL. BC-423

Physalis pubescens L. var. pubescens (Downy Ground-Cherry). US; I; FAC. BC-1310

Solanum carolinense L. var. carolinense (Carolina Horse-Nettle). LO; I; FACU. BC-550

oSolanum emulans Raf. (Eastern Black Nightshade). US; I; FACU. $B C-238$

O*Solanum lycopersicum L. (Tomato). US; S; NI. BC-549, BC-1015
O*Solanum sarrachoides Sendtner (Hairy Nightshade). US; R; NI. BC-1505

\section{Ulmaceae}

Ulmus americana L. var. americana (American Elm). LO, BHF; A; FACW. BC-42, BC-1546

\section{Urticaceae}

Boehmeria cylindrica (L.) Swartz (False-Nettle). LO, BHF; A; FACW. $B C-553$

Laportea canadensis (L.) Weddell (Canada Wood-Nettle_. LO, BHF; A; FACW. BC-554, BC-1536

Pilea pumila (L.) A. Gray (Greenfruit Clearweed). LO, BHF; A; FACW. $B C-1106$

oUrtica gracilis Aiton ssp. gracilis (American Stinging-Nettle). LO, BHF; A; FAC. BC-1530

\section{Verbenaceae}

Phyla lanceolata (Michx.) Greene (Marsh Frogfruit). US, REW; I; OBL. BC-543

Verbena hastata L. (Blue Vervain). LO; S; FACW. BC-433, BC-1533

Verbena urticifolia L. (White Vervain). LO; O; FAC. BC-447

\section{Viburnaceae}

Sambucus canadensis L. (Common Elderberry). LO, BHF; F; FACW. $B C-282$

\section{Violaceae}

oViola sororia Willd. var. sororia (Common Blue Violet). LO, BHF; A; FAC. BC-62

oViola striata Aiton (Cream Violet). LO, BHF; O; FACW. BC-119

\section{Vitaceae}

Ampelopsis cordata Michx. (Raccoon Grape). LO, BHF; O; FAC. BC-244 Parthenocissus quinquefolia (L.) Planchon (Virginia-Creeper). LO, BHF; F; FACU. BC-250

oVitis riparia Michx. (Riverbank Grape). US, LO, BHF; A; FACW. BC-616 Vitis vulpina L. (Frost Grape). US, LO, BHF; A; FAC. BC-246, BC-1124

\section{CONCLUSIONS}

Brush Creek Island, as a Kentucky Ohio River island, will have its future flora and vegetation determined to a great extent by its physical features (the environmental complex) and existing vegetation. Brush Creek Island continues to be influenced and shaped by the dynamic fluvial processes of the Ohio River through severe erosion, abrasive mechanical damage, and transportation and deposition of light to heavy sediments.

Brush Creek Island has a very high species richness (330 taxa) for a small 6.7-ha freshwater island in comparison to other recently studied river island floras in the eastern United States. This high species richness is strongly affected by Ohio River flooding regimes and hydrology in conjunction with the current and former habitats on Brush Creek Island. The Bottomland Hardwood Forest [Acer-Ulmus-Celtis-JuglansPlatanus-Populus Community] remains the final climax sere derived in part from the sub-sere of Late Old Field and Immature Bottomland Hardwood Forest.

Ohio River fluvial effects include the influx of new native and non-native plant propagules (seeds, fruits, spores, plant parts) as well as the extirpation of some present-day and past plant species on the Ohio River Islands. The Ohio River remains an important corridor for the migration, establishment, colonization, and spread of native and non-native naturalized and invasive plants. Ultimately, non-native invasive species will continue to have deleterious ecosystem structure and function effects on the flora and vegetation of Brush Creek Island. 


\section{ACKNOWLEDGMENTS}

We extend our appreciation to Patricia A. (Schettig) Morrison, U.S. Fish and Wildlife Biologist, Retired, the Ohio River Islands National Wildlife Refuge, St. Marys, West Virginia, for encouragement, transportation, and technical data during this study. We offer sincere gratitude to J. Richard Abbott, University of Arkansas at Monticello; Ronald L. Jones, Eastern Kentucky University; Paul F. Threadgill, Maryville College; and Charles E. Williams, Columbia Southern University, for their valued constructive and through reviews. Special thanks are given to J. Richard Abbott, Gary W. Libby, and Andy E. Shupe, Berea College Biology graduates, for companionship during field trips. Appreciation is extended to Melanie J. Givan, Eastern Kentucky University, for Fig. 1 and Fig. 3 maps, and to Tom Cross, Executive Director, Adams County Travel and Visitor Bureau, West Union, Ohio, for the Fig. 2 photo of Brush Creek Island. We are grateful for the financial support of this article from Hancock Biological Station, Murray State University.

\section{REFERENCES}

Aввотт, J.R., R.L. Thомpson, \& R.A. Gelis. 2004. Noteworthy vascular plants from Kentucky: A state record, range extensions, and various species of interest. J. Kentucky Acad. Sci. 65:94-103.

BAILEY, W.J. 1978. The distribution of flood plain herbs as influenced by annual flood elevation. Wisconsin Acad. Sci., Arts \& Letters 66:254-266.

BAlLEY, W.J. 1991. Tree populations on the islands of the lower Chippewa River in Wisconsin. Bull. Torrey Bot. Club 118:424-431.

BeAL, E.O. \& J.W. Thieret. 1986. Aquatic and wetland plants of Kentucky. Kentucky Nature Preserves Commission, Scientific and Technical Series, No. 5.

Braun, E.L. 1950. Deciduous forests of eastern North America. Hafner Press, New York, U.S.A.

CAmpBeLL, J. \& M. Medley. 2006. Illustrated atlas of vascular plants in Kentucky: A first approximation. Draft of July 2006. Bound manuscript distributed by authors, Lexington, Kentucky, U.S.A.

CAmpbelL, J. \& M. Medley. 2012. The atlas of vascular plants in Kentucky. Draft of January 2012, with provisional listing of authors. Available at htpp://bluegrasswoodland.com. Accessed Oct 2019.

CAmpBeLL, J.J.N. \& M.E. MedLEy. 2020. Kentucky plant atlas. Available at http://carexmisera.com/ KyPlantAtlas/. Accessed Mar 2021.

Daubenmire, R. 1968. Plant communities: A textbook of plant synecology, Harper \& Row, New York, U.S.A.

DYER, J.M. 2006. Revisiting the deciduous forest of eastern North America. BioScience 56:341-352.

GeuI, R.A. 1996. Birds of Manchester 1, Manchester 2, and Brush Creek Islands, Ohio River Islands National Wildlife Refuge, Lewis County, Kentucky. The Kentucky Warbler 72:20-25.

Google EarTH Pro. 2016. Brush Creek Island, Kentucky. US Department of State Geographers, GeoBasis-DE/BKG Data SIO, NOAA. Available at http://geo2.scholarsportal.info/. Accessed Mar 2021.

Hood, W.G. \& R.J. NaImAN. 2000. Vulnerability of riparian zones to invasion by exotic vascular plants. PI. Ecology 148:105-114.

JACOBS, S.E. \& R.D. JonES. 2004. Soil survey of Lewis County, Kentucky. Concord Quadrangle 7.5-minute series. U.S. Department Agriculture, Natural Resources Conservation Service. Washington, D.C., U.S.A.

JONES, R.L. 2005. Plant life of Kentucky: An illustrated guide to the vascular flora. University Press of Kentucky. Lexington, Kentucky, U.S.A.

KY-EPPC. 2013. Kentucky Exotic Plant Pest Council, $3^{\text {rd }}$ Edition. Invasive exotic plant list. Available at http://www.seeppc.org/ky/list.htm. Accessed Aug 2020.

LichVAR, R.W. 2013. The National Wetland Plant List: 2013 wetland ranges. Phytoneuron 2013-49:1-241. Published 17 July 2013. ISSN 2153 733X.

MRCC (Midwest Regional Climate Center). 2019. Climate of the Midwest. Kentucky: Maysville Sewage Plant Station (155243). Available at http://mrcc.isws.illinois.edu/climate_midwest/ mwclimate_data_summaries.hth. Accessed May 2019.

MoRRIS, R.H. 1966. Geologic map of part of the Concord and Buena Vista Quadrangle, GQ-525, Lewis County, Kentucky. U.S. Geologic Survey, Washington, D.C., U.S.A.

NaImAn, R.J. \& H. DéCAmps. 1997. The ecology of interfaces: Riparian zones. Ann. Rev. Ecol. Syst. 28:621-659. 
NaImAn, R.J., H. DÉCAMPS, \& M.E. McClain. 2005. Riparia: Ecology, conservation, and management of streamside communities. Elsevier Academic Press, New York, U.S.A.

OKNP (Office of Kentucky Nature Preserves). 2019. Endangered, threatened, and special concern plants, animals, and natural communities of Kentucky. Available at https://eec.ky.gov/ Nature-Preserves/biodiversity/Documents/ Rare_species_of_Kentucky.pdf. Accessed May 2020.

ORINWR (Ohio River Islands National Wildlife Refuge). 2002. ORINWR final comprehensive conservation plan (CCP): updated refuge 2016 plant list. Available at https://www.fws.gov/refuge/ Ohio_River_Islands/ what_we_do/conservation.html. Accessed Jun 2020.

Richardson, D.M., P. Pyšek, M. Rejamánek, M.G. Barbour, F. Dane Panetta, \& C.J. West. 2000. Naturalization and invasion of alien plants: concepts and definitions. Diversity \& Distrib. 6:93-107.

Richardson, D.M., P.M. Holmes, K.J. Esler, S.M. Galatowitsch, J.C. Stromberg, S.P. Kirkman, P. Pyšek, \& R.I. Hobbs. 2007. Riparian vegetation: degradation, alien plant invasions, and restoration prospects. Diversity \& Distrib. 13:126-139.

SChwarTZ, L.M., D.J. GiBSon, \& B.G. Young. 2016. Life history of Achyranthes japonica (Amaranthaceae): An invasive species in southern Illinois. J. Torrey Bot. Soc. 143:93-192.

SERNEC Data Portal. 2021. SouthEast Regional Network of Expertise and Collections. Available at http//sernec portal. org/index.php. Accessed Mar 2021.

SPRINGER, F.M., C.R. UlLRICH, \& D.J. HAGERTY. 1985. Streambank stability. J. Geotechnical Engineering 111:624-640.

THOMPSON, R.L. \& K. Rivers THOMPSON. 2016. Vascular plants and plant communities of Wickliffe Mounds State Historic Site, Ballard County, Kentucky. J. Bot. Res. Inst. Texas 10:245-266.

Toun, W.A. \& P.A. Schettig. 1983. A physical and biological survey of the Ohio River Islands (Manchester District). U.S. Department of the Interior, U.S. Fish and Wildlife Service, Elkins, West Virginia, U.S.A.

Trewartha, G.T. \& L.H. HoRn. 1980. An introduction to climate, $5^{\text {th }}$ Edition. McGraw-Hill Book Company, New York, U.S.A. USDA, NRCS. 2020. The PLANTS Database (http://plants.usda.gov/). National Plant Data Team, Greensboro, North Carolina 27401-4901, U.S.A.

VAnCE, J.A., N.B. Angus, J.S. Rentch, \& J.T. Anderson. 2014. Vegetation and soil parameters at an island bridge crossing. Castanea 79:59-73.

WALTERS, G.L. \& C.E. WiLLIAMs. 1999. Riparian forest overstory and herbaceous layer of two Upper Allegheny River Islands in northwestern Pennsylvania. Castanea 64:81-89.

WEAKLEY, A.S. 2015. Flora of the southern and mid-Atlantic states, working draft of 28 September 2015. University of North Carolina Herbarium (UNC), North Carolina Botanical Garden, Chapel Hill, North Carolina, U.S.A. Available at http://www.herbarium.unc.edu/flora.htm. Accessed 28 Feb 2020.

WeAkLEY, A.S. 2020. Flora of southeastern United States. Edition of 20 October 2020. University of North Carolina at Chapel Hill Herbarium (NCU) and North Carolina Botanical Garden, Chapel Hill, North Carolina. Available at https:// ncbgunc.edu/FSUS/2020/FSUS.pdf. Accessed Mar 2021.

WhitBaCK, J.J., G.G. HARTMAN, \& F.J. Brenner. 1997. Botanical survey of two islands in the middle Allegheny River corridor. J. Pennsylvania Acad. Sci. 71:3-9.

WiLlams, C.E. 2010a. Survey of the alien flora of the Allegheny River Islands Wilderness, Pennsylvania. Rhodora 112:142-155.

WiLlams, C.E. 2010b. Sweet-scented Indian-plantain, Hasteola suaveolens (L.) Pojark, in riparian plant communities of the Allegheny River Islands Wilderness, Pennsylvania. Castanea 75:444-453.

Woods, A.J., J.M. Omernik, W.H. Martin, G.J. Pond, W.M. Andrews, S.M. Call, J.A. Comstock, \& D.D. TAYlor. 2002. Ecoregions of Kentucky (color poster with map, descriptive text, summary tables, and photographs). Map scale 1:1,000,000. United States Geological Survey, Reston, Virginia, U.S.A. 